\title{
Unilaterální přechodný erytém - fenomén Harlekýn
}

\section{MUDr. Jan Hálek, Ph.D., MUDr. Hana Zedníčková-Škodová, MUDr. Eva Bazgerová Novorozenecké oddělení a Dětská klinika FN Olomouc}

\section{Klíčová slova: unilaterální erytém, Harlekýn, novorozenec.}

Key words: unilateral erythema, Harlequin, newborn.

Chlapec se narodil z fyziologické gravidity, v termínu, časná poporodní adaptace probíhala výborně. Byl plně kojený, propuštěný do domácí péče, prospívající, bez potíží. Asi od 10. dne života se začalo objevovat zarudnutí poloviny obličeje - s ostrým ohraničením oproti druhé, bledé polovině. Většinou se příznak objevil při kojení, když byl chlapeček otočený na levý bok, ale nikoliv výhradně. Kromě polohy nebyl provokován žádnými zvláštními okolnostmi, nebyl doprovázen jinými př́znaky. Zarudnutí vždy spontánně ustoupilo - do 10 minut, objevovalo se opakovaně, nepravidelně, několikrát denně. Četnost výskytu se postupně snižovala.

Unilaterální přechodný erytém - kožní změny typu Harlekýn' - je benigním kožním projevem, který se dle literárních zdrojů objevuje až u 10 \% novorozenců (zralých i nezra-

1 Termín "harlekýn“ je používán také pro popis klinického obrazu dětí se závažnou kongenitální formou ichtyózy. (V tomto prípadě pro jejich „smutný" výraz.) lých). Popsán byl poprvé v padesátých letech minulého století. Nejčastěji se objevuje mezi 2. a 5. dnem života, ale může se objevit i krátce po narození nebo i v několika týdnech. Projev je charakterizovaný náhlým vznikem zarudnutí obvykle poloviny obličeje nebo trupu, s ostrým ohraničením vůči druhé polovině těla, která je bledá. Jsou ale popisovány i jiné varianty nerespektující toto klasické rozdělení (končetiny, šourek atd.). Projev je přechodný, vymizí spontánně do několika vteřin až 20 minut. Může se objevit opakovaně, ústup je spontánní - obvykle do několika týdnů - maximálně měsíců.

Jeho př́ičina je nejasná, pravděpodobně je způsoben nezralostí mechanismů regulujících průtok cévním řečištěm. Prognosticky jde o jednoznačně benigní projev: je sice popisován i u dětí s některými onemocněními (meningitis, traumata CNS atd.), ale i v těchto prípadech jde o epifenomén, ne o základní príznak onemocnění. Vzhledem k tomu, že jde o poměrně častý fenomén, je určitě vhodné být s jeho cha- rakterem seznámen. Neznalost může vést ke zbytečným obavám - u rodičů i zdravotníků a prípadně vést k nadbytečným vyšetřením.

Obr. 1. Unilaterální erytém

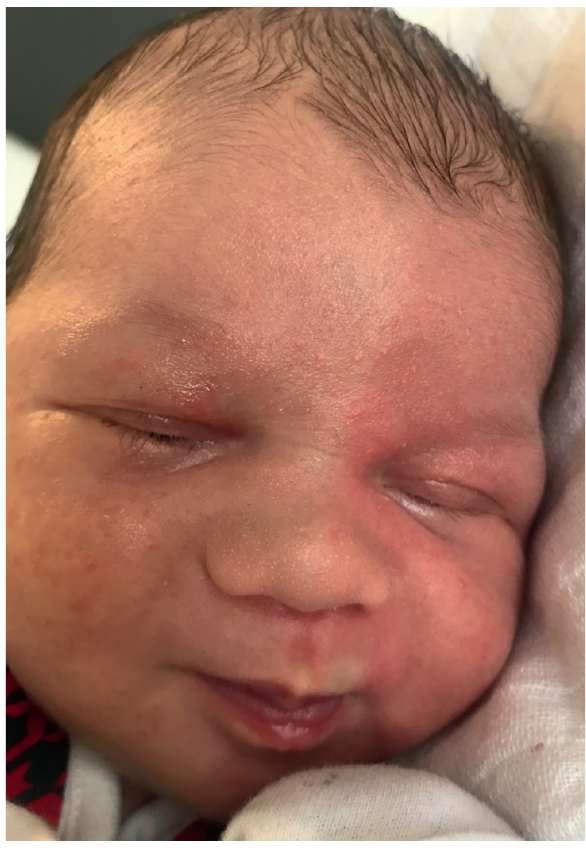

